\title{
Meal Data Elapsed Time
}

National Cancer Institute

\section{Source}

National Cancer Institute. Meal Data Elapsed Time. NCI Thesaurus. Code C162263.

The interval between two meal data reference time points. 